\title{
KARAKTERISTIK TEPUNG PREMIKS BERBAHAN MOCAF (MODIFIED CASSAVA FLOUR) DAN MAIZENA PADA PEMBUATAN COOKIES GREEN TEA
}

\section{Characteristic of Premix Flour Cookies Green Tea from Mocaf (Modified Cassava Flour) and Maize}

\author{
Nurud Diniyah $^{1 \star}$, Fatimah Wahyu ${ }^{1}$, Achmad Subagio $^{1}$ \\ Jurusan Teknologi Hasil Pertanian, FTP Universitas Jember \\ Jl. Kalimantan 37, Kampus Tegal Boto Jember 68121 \\ *Penulis Korespondensi, e-mail: nurud.ftp@unej.ac.id
}

\begin{abstract}
ABSTRAK
Penelitian ini bertujuan untuk mempelajari hubungan formulasi MOCAF dan maizena dan waktu penyimpanan terhadap nilai kadar air, aw (tepung premiks), sifat fisik kimia dan organoleptik (cookies) berdasarkan formula terbaik. Rancangan Acak Lengkap (RAL) dua faktor digunakan dalam penelitian ini. Formulasi MOCAF dan maizena (100:0, 95:5, 90:10, $85: 15,80: 20,75: 25$, dan 70:30\%) sebagai faktor pertama dan lama penyimpanan sebagai faktor kedua (0, 1 dan 2 minggu). Hasil formula terbaik dilakukan analisis proksimat dan uji organoleptik. Proporsi MOCAF dan maizena pada tepung premiks cookies berpengaruh nyata dan menyebabkan peningkatan terhadap nilai kadar air, aktivitas air (tepung premiks), daya patah, chroma, dan lightness (cookies) dengan perlakuan terbaik yaitu formulasi $75 \%$ MOCAF dan $25 \%$ maizena) dengan lama penyimpanan 2 minggu.
\end{abstract}

Kata Kunci: cookies, MOCAF, tepung premiks, waktu penyimpanan

\section{ABSTRACT}

The aims of this research are to determine the effect of formulation MOCAF and maize to the value of water content, water activity of premix flour and time of flour storage, the physiochemical and organoleptic characteristics of cookies, based on the best formulation. This research uses Random Design Complete (RAL) with two factors, the formulation of MOCAF and maize (100:0, 95:5, 90:10, 85:15, 80:20, 75:25, 70:30\%) and time of storage (0, 1 and 2 weeks). The results showed that the formula of MOCAF and maize on the flour of premix cookies had a significant effect and resulted in the increase of the water content value, the water activity (premix flour), fracture, chroma, and lightness (cookies). The best treatment was obtained at the formulation $75 \%$ MOCAF: $25 \%$ maize with 2 weeks time stotage.

Keywords: cookies, MOCAF, premix flour, time of storage

\section{PENDAHULUAN}

Dalam beberapa tahun terakhir, dilaporkan bahwa terdapat data peningkatan yang signifikan terhadap permintaan makanan siap saji tidak hanya di Indonesia tetapi juga Thailand dan Vietnam (Company Report, 2016). Produk tepung siap pakai/premiks merupakan produk yang terdiri dari beberapa komponen bahan tepung yang disatukan menjadi satu. Dalam pembuatan tepung premiks terdapat beberapa bahan tepung yang dicampurkan seperti susu, gula bubuk, essence bubuk, dan lain-lain. Bahan-bahan yang bersifat cair umumnya tidak ditambahkan ke dalam tepung premiks, seperti air, lemak (seperti margarin, shortening, butter, dan minyak sayur) serta telur. Penggunaan tepung premiks dengan mencampurkan beberapa jenis tepung yang berbeda dimaksudkan dapat mensubstitusi komponen tertentu secara partial dimaksudkan dapat menekan harga menjadi 
lebih murah. Beberapa keunggulan penggunaan tepung premiks yaitu waktu lebih efisien, lebih ekonomis, dan tidak bulky sehingga lebih efektif (Santoso, 2009). Mayoritas produk tepung premiks menggunakan terigu, sehingga untuk mengurangi pemakaian terigu salah satu alternatifnya dapat menggunakan MOCAF.

MOCAF (Modified Cassava Flour) dapat diproduksi dari singkong (Manihot esculenta Crantz) dengan prinsip memodifikasi sel singkong dengan proses fermentasi BAL (Bakteri Asam Laktat) (Subagio et al., 2008). Daya kembang MOCAF setara dengan gandum tipe II (kadar protein menengah) (Rachman, 2012). MOCAF telah banyak diaplikasikan menjadi kue bika ambon (Diniyah dkk, 2013), beras analog (Diniyah et al, 2016), indeks glikemik beras analog (Diniyah et al., 2016), rempeyek (Nadhifah et al., 2016), mi mojang (Diniyah et al., 2017), teknik ekstrusi mi mojang (Diniyah et al., 2017), tepung bumbu (Anwar et al., 2016) dan yang lainnya. Oleh karena itu MOCAF sangat sesuai jika digunakan dalam pembuatan cookies.

Cookies adalah salah satu jenis produk makanan konvensional yang paling popular di daerah pedesaan dan perkotaan (Banerjee et al., 2014). Cookies dianggap sebagai makanan yang terkonsentrasi karena tingginya kandungan karbohidrat, lemak dan kadar air yang rendah (Skrbic \& Cvejanov, 2011), memerlukan tepung dengan kadar protein rendah sebesar $8 \%-9,5 \%$ dan secara alternatife diproses dengan menambahkan tepung mengandung gluten $<1 \%$ (Rosmisari, 2006). Selain MOCAF dalam pembuatan cookies dibutuhkan bahan lain untuk substitusi yaitu maizena. Maizena berperan sebagai bahan pengikat yang menghasilkan tekstur renyah pada cookies (Utomo et al., 2017). Pengembangan lain produk cookies adalah penambahan green tea yang berperan sebagai antioksidan sehingga dapat mencegah proses oksidasi produk selama penyimpanan dan juga sebagai perisai cookies. Dari sudut pandang gizi, kualitas cookies dapat ditingkatkan dengan menambahkan sejumlah bahan seperti yang telah dipaparkan dalam pembuatan tepung premiks sehingga didapatkan cookies dengan karakteristik fisik, kimia dan sensori yang diterima oleh konsumen.

Penelitian ini bertujuan untuk mempelajari pengaruh formulasi MOCAF dan maizena terhadap nilai kadar air, dan Aw tepung premiks dengan waktu penyimpanan tepung, dan melakukan karakterisasi fisik cookies, serta sifat kimia dan organoleptik cookies berdasarkan formula terbaik.

\section{Bahan}

\section{BAHAN DAN METODE}

Bahan baku pembuatan tepung premiks cookies yaitu MOCAF yang diperoleh dari CV. Bangkit Cassava Mandiri, maizena, green tea powder, gula halus cap mawar, vanilla powder cap mobil, susu full cream grade A, garam, minyak sayur, mentega, telur didapatkan dari pasar tradisional Jember, serta bahan kimia untuk analisis kimia yang diperoleh dari Laboratorium Kimia dan Biokimia Pangan Fakultas Teknologi Pertanian Universitas Jember.

Alat

Alat-alat yang dipakai yaitu oven dan mixer merk kirin, loyang, neraca analitik ohaus, kuas, pisau, cetakan cookies, tekstur analyzer (Brookfield CT3), desikator, oven memmert, colour reader (Minolta CR-10), soxhlet, kjeldahl, tanur, cawan porselin, botol timbang.

\section{Desain Penelitian}

Penelitian dilakukan menggunakan Rancangan Acak Lengkap (RAL) faktorial, terdiri dari dua faktor yaitu rasio MOCAF dan maizena (100: 0; 95:5; 90:10; 85:15; 80:20; 75:2; 70:30) dan waktu penyimpanan (0,1 dan 2 minggu) dengan tiga kali ulangan. Penelitian dilakukan dua tahapan, yaitu pembuatan tepung premiks cookies dan dilanjutkan dengan membuat cookies. Data yang didapatkan diuji dengan analisis sidik ragam dan dilanjutkan uji Duncan New Multiple Range Test (DMRT) pada taraf uji $\alpha \leq 5 \%$ menggunakan Minitab 17, apabila terdapat perbedaan. 


\section{Tahap Penelitian}

Tahap satu adalah pembuatan tepung premiks yang meliputi penimbangan bahan flour mix (MOCAF, maizena) sesuai formula, konsentrasi green tea, gula, susu, vanilla, garam adalah sama. Pencampuran semua bahan dan pengayakan menggunakan ukuran 80 mesh sehingga didapatkan ukuran yang lebih seragam atau halus. Tepung premiks disimpan sesuai perlakuan.

Tahap kedua adalah proses pembuatan cookies yang meliputi pencampuran bahan pembantu dengan bahan utama flour mix (sesuai perlakuan), pencetakan, pemanggangan (oven) dengan suhu $160^{\circ} \mathrm{C}$ selama 16 menit.

\section{Prosedur Analisis}

Parameter pengamatan terhadap tepung premiks meliputi kadar air dan aktivitas air (AOAC, 2000). Sedangkan analisis terhadap cookies meliputi kekerasan (Uthumporn et al., 2014 dengan modifikasi), daya patah (Okaka and Isieh, 1990 dengan modifikasi), chroma, lightness (Hutching, 1999). Perlakuan terbaik (De Garmo et al., 1984) diambil dari dua sampel dengan nilai tertinggi dan dilakukan analisis sifat organoleptik dan proksimat (kadar air, protein, lemak, abu (AOAC, 2000) dan karbohidrat by different).

\section{HASIL DAN PEMBAHASAN}

\section{Analisis Tepung Premiks \\ Kadar Air}

Hasil analisis kadar air tepung premiks cookies berkisar antara $8.53 \%$ sampai $9.12 \%$. Berdasarkan hasil ANOVA pada taraf uji $5 \%$ didapatkan angka yang berbeda nyata pada formula MOCAF dan penambahan maizena dan waktu penyimpanan tepung premiks. Nilai kadar air tepung premiks cookies (Tabel 1).

Tabel 1. Kadar Air dan Aktivitas Air Tepung Premiks Cookies Green Tea

\begin{tabular}{|c|c|c|c|}
\hline Lama Penyimpanan (Minggu) & Rasio MOCAF:maizena & Kadar Air (\%) & Aktivitas Air \\
\hline \multirow[t]{7}{*}{0} & 100:0 & 8.87bcde & $0.59 \mathrm{cdef}$ \\
\hline & $95: 5$ & 8.82defg & 0.58defg \\
\hline & $90: 10$ & 8.78bcdef & $0.58 f g h i$ \\
\hline & $85: 15$ & 8.72gh & $0.57 \mathrm{jkl}$ \\
\hline & $80: 20$ & 8.68hi & $0.57 \mathrm{kl}$ \\
\hline & $75: 25$ & $8.55 \mathrm{j}$ & 0.571 \\
\hline & $70: 30$ & $8.53 j$ & $0.56 \mathrm{kl}$ \\
\hline \multirow[t]{7}{*}{1} & $100: 0$ & $8.92 b c$ & $0.59 \mathrm{bc}$ \\
\hline & $95: 5$ & 8.87bcde & $0.59 b c$ \\
\hline & $90: 10$ & 8.82defg & $0.59 \mathrm{cdef}$ \\
\hline & $85: 15$ & $8.77 \mathrm{fgh}$ & 0.58ghij \\
\hline & $80: 20$ & $8.72 \mathrm{gh}$ & $0.58 \mathrm{hijk}$ \\
\hline & $75: 25$ & $8.62 \mathrm{ij}$ & $0.58 \mathrm{ijk} \mid$ \\
\hline & $70: 30$ & $8.6 \mathrm{ij}$ & $0.57 \mathrm{kl}$ \\
\hline \multirow[t]{7}{*}{2} & $100: 0$ & $9.12 a$ & $0.61 a$ \\
\hline & $95: 5$ & $9.07 a$ & $0.61 a$ \\
\hline & $90: 10$ & $9.03 a$ & $0.60 \mathrm{~b}$ \\
\hline & $85: 15$ & $8.93 b$ & $0.60 \mathrm{~b}$ \\
\hline & $80: 20$ & $8.88 \mathrm{bcd}$ & $0.59 \mathrm{cdef}$ \\
\hline & $75: 25$ & 8.83cdef & 0.58 defg \\
\hline & $70: 30$ & 8.78efg & 0.58 efgh \\
\hline
\end{tabular}

Kadar air tepung premiks cookies grean tea sebanding dengan tepung premiks biscuit (8.1\%) (Kumar et al, 2015), 7.27-8.13\% (Kumar et al., 2015). Rerata kadar air tepung premiks cookies grean tea masih sesuai Standar Nasional Indonesia (SNI) tentang tepung 
campuran siap pakai yaitu maksimal $12 \%$. Nilai kadar air tepung premiks semakin menurun seiring dengan penambahan maizena, ini dikarenakan kadar air maizena (10\%) lebih rendah daripada kadar air MOCAF (14\%). Sebaliknya, waktu penyimpanan yang makin lama menunjukkan adanya peningkatan kadar air tepung premiks tetapi peningkatan tersebut masih dalam batas minimal kadar air yang disyaratkan pada tepung campuran siap pakai berdasarkan SNI (12\%).

\section{Aktivitas Air}

Hasil analisis aktivitas air tepung premiks cookies berkisar antara 0.563 sampai 0.61 . Berdasarkan hasil ANOVA pada taraf uji $5 \%$ didapatkan nilai yang berbeda nyata pada formula MOCAF dan maizena serta lama waktu penyimpanan tepung premiks cookies. Nilai aktivitas air tepung premiks cookies (Tabel 1). Rentang nilai rata-rata dari aktivitas air tersebut menunjukkan bahwa aktivitas air dari tepung premiks cookies green tea telah memenuhi syarat tidak lebih dari 0.7. Nilai aktivitas air sebanding dengan nilai kadar air, jika nilai kadar air tepung premik naik maka nilai aktivitas air juga naik. Aktivitas air meningkat dengan semakin lama waktu penyimpanan. Pada Tabel 1 terlihat adanya kenaikan yang nyata selama penyimpanan 0 minggu hingga 2 minggu. Kenaikan aktivitas air selama penyimpanan disebabkan oleh penyerapan air yang ada di lingkungan oleh produk. Produk berbasis tepung lebih mudah menyerap air disekitar sehingga menyebabkan aktivitas air produk cenderung mengalami kenaikan (Estiasih \& Ahmadi, 2009).

\section{Analisis Cookies}

Hardness (kekerasan)

Hasil analisis kekerasan cookies berkisar antara 0.055 sampai $0.15 \mathrm{~g} / \mathrm{mm}$. Berdasarkan hasil ANOVA pada taraf uji $5 \%$ dihasilkan nilai yang berbeda nyata pada penambahan maizena dan lama waktu penyimpanan tepung premiks cookies. Nilai kekerasan tepung premiks cookies dapat dilihat pada Gambar 1. Tingkat kekerasan cookies green tea menurun seiring dengan bertambahnya maizena dan berkurangnya MOCAF, ini dikarenakan pada MOCAF komponen penyusunnya masih terdapat kandungan serat (1.93.4\%) (Subagio et al., 2008). Penambahan maizena yang semakin banyak menyebabkan tingkat kekerasan cookies semakin meningkat karena pada maizena komponen terbesar adalah pati yaitu antara 95.37-97.98\% dengan kandungan amilosa 37.10-57.29\% (Rambitan, 1988; Tovar et al., 2002).

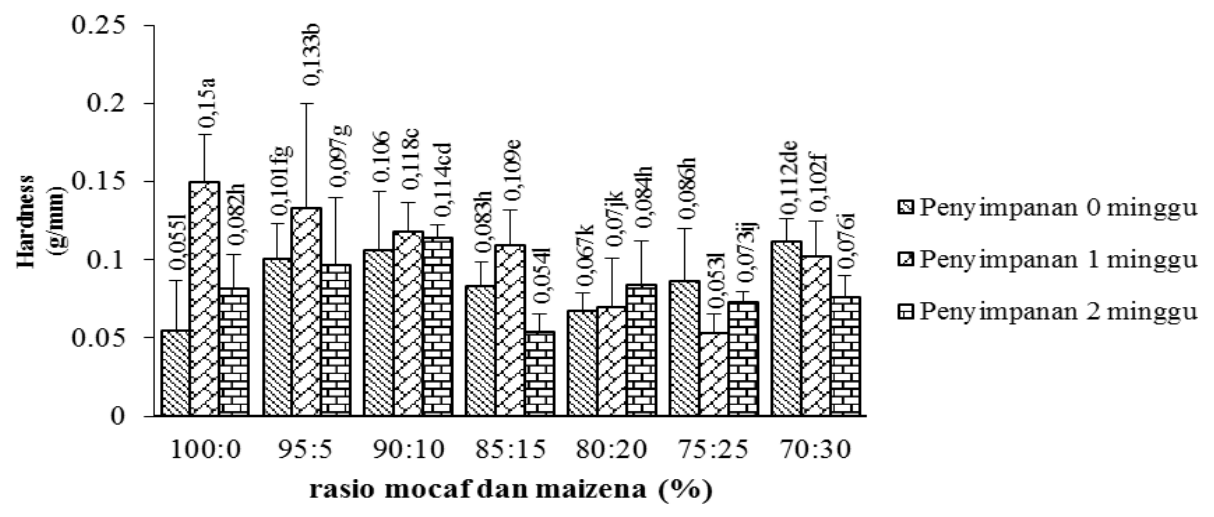

Gambar 1. Grafik Nilai Kekerasan (Hardness) Cookies Green Tea

Bentuk kristalin amilosa berdampak molekul pati lebih rapuh bila ditambahkan sebagai bahan baku (tepung singkong, sagu, tepung terigu, pati jagung) dalam pembuatan produk (Tongdang et al., 2008; Saeleaw and Schleining, 2010; Taewee, 2011). Menurut Apriyani et al. (2011), produk bertekstur relatif keras linier dengan makin tinggi tingkat kekerasan dan menjadi kurang renyah jika dibandingkan dengan produk yang tingkat 
kekerasannya rendah. Menurun nya nilai kekerasan pada cookies menunjukkan bahwa produk lebih renyah sehingga lebih mudah patah. Waktu penyimpanan yang semakin lama menunjukkan tingkat kekerasan cookies semakin meningkat. Penambahan pati jagung mempengaruhi tekstur dari cookies secara signifikan pada lama penyimpanan suhu ruang (Perez-Carrillo et al., 2017).

\section{Fracture (daya patah)}

Hasil analisis daya patah cookies berkisar antara $68.242 \mathrm{~g} / \mathrm{mm}$ sampai $163.86 \mathrm{~g} / \mathrm{mm}$. Berdasarkan hasil ANOVA pada taraf uji $5 \%$ dihasilkan nilai yang berbeda nyata pada penambahan maizena dan lama waktu penyimpanan tepung premiks cookies. Nilai daya patah cookies dapat dilihat pada Gambar 2. Rentang nilai rata-rata daya patah menunjukkan kecenderungan bahwa semakin banyak penambahan maizena mengakibatkan naiknya daya patah cookies green tea. Peningkatan kekerasan crumb dapat disebabkan karena rekristalisasi amilosa dan amilopektin, formasi kompleks antara pati dan protein dan redistribusi air dengan komponen dalam produk seperti yang terjadi pada penyimpanan produk bakery. Kandungan amilosa dari semakin banyaknya penambahan maizena menyebabkan cookies lebih mudah dipatahkan karena amilosa memiliki kemampuan menyerap air yang tinggi sehingga granula pati mengalami pembengkakan selama proses gelatinisasi pada saat pemanggangan. Pada proses pemanggangan, air yang terserap oleh pati dapat meninggalkan ruang kosong dalam adonan dan tekstur cookies menjadi renyah sehingga mudah patah (Seyhun et al., 2003). Sejalan dengan Prameswari dan Estiasih (2018), kerenyahan cookies umbi gembili meningkat dengan meningkatnya penambahan pati jagung.

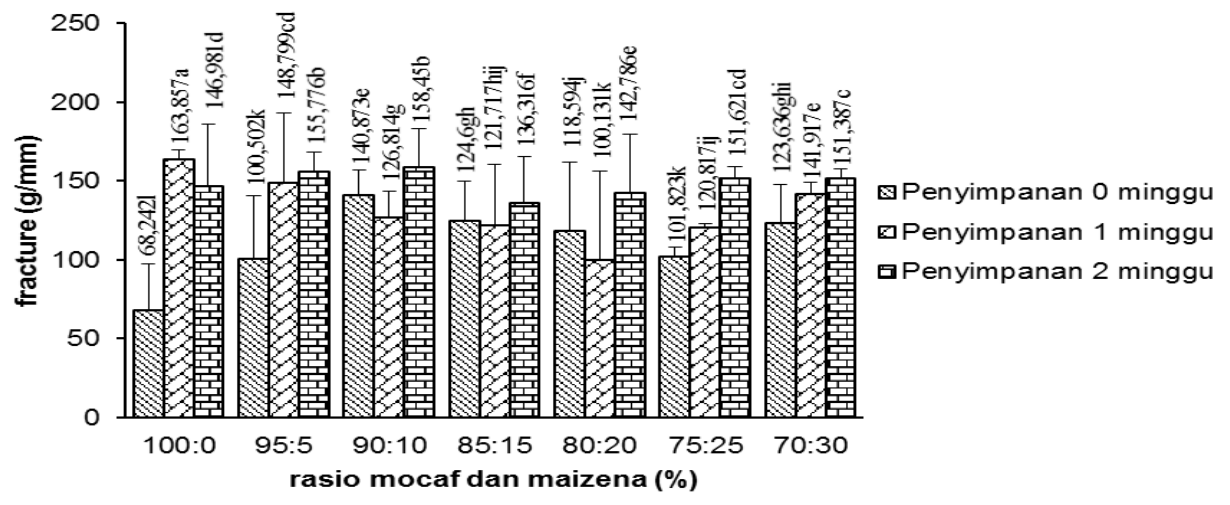

Gambar 2. Grafik Nilai Daya Patah (Fracture) Cookies Green Tea

\section{Chroma}

Hasil analisis nilai chroma cookies berkisar antara 22.96 sampai 28.59. Berdasarkan hasil ANOVA pada taraf uji $5 \%$ dihasilkan nilai chroma yang berbeda nyata pada penambahan maizena dan lama waktu penyimpanan tepung premiks yang dibuat menjadi cookies. Nilai chroma cookies dapat dilihat pada Gambar 3. Semakin banyak penambahan maizena maka nilai chroma yang dihasilkan cenderung mengalami kenaikan. Ini disebabkan karena maizena memiliki tingkat kecerahan atau derajat putih (> 94\%) (BSN, 1994) yang lebih tinggi jika dibandingkan dengan MOCAF (derajat putih min 87\%) (BSN, 2011). Sedangkan selama penyimpanan, nilai chroma cookies cenderung mengalami penurunan. Perubahan derajat warna tepung dipengaruhi oleh penyimpanan yang secara signifikan sehingga menyebabkan penurunan nilai warna karena terjadinya proses oksidasi terhadap warna tepung secara alami dan adanya oksigen serta enzim yang membantu terjadinya perombakan selama penyimpanan tersebut (Ahmed, 2015). 


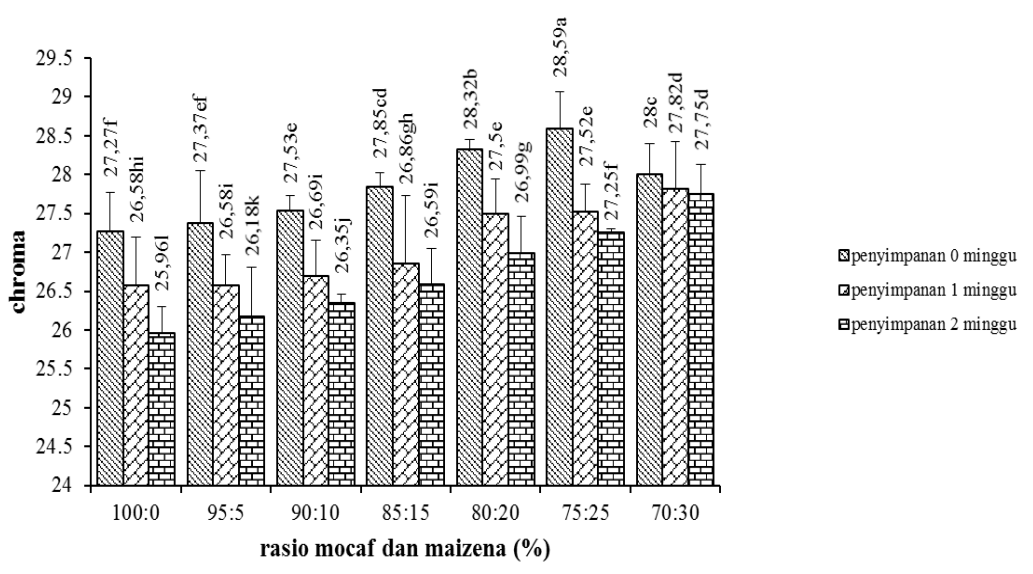

Gambar 3. Grafik Nilai Chroma Cookies Green Tea

\section{Lightness}

Hasil analisis nilai lightness cookies berkisar antara 60.42 sampai 63.587 . Berdasarkan hasil ANOVA pada taraf uji $5 \%$ dihasilkan nilai lightness yang berbeda nyata pada penambahan maizena dan lama waktu penyimpanan tepung premiks yang dibuat menjadi cookies. Nilai lightness cookies dapat dilihat pada Gambar 4. Semakin banyak penambahan maizena maka nilai lightness yang dihasilkan cenderung mengalami kenaikan. Maizena sebagai bahan baku memiliki kecerahan lebih tinggi dibandingkan dengan MOCAF. Berdasarkan SNI, nilai derajat putih maizena > 94\% (BSN, 1994) lebih putih jika dibandingkan dengan MOCAF (derajat putih min 87\%) (BSN, 2011). Lama penyimpanan produk tepung premiks yang semakin panjang menjadikan warna cookies yang dihasilkan semakin rendah. Selama penyimpanan tepung mudah mengalami oksidasi akibat udara disekitar sehingga menurunkan tingkat kecerahannya. Sejalan dengan Kumar et al (2015), adanya penambahan maizena dapat meningkatkan lightness tepung premiks dari biskuit.

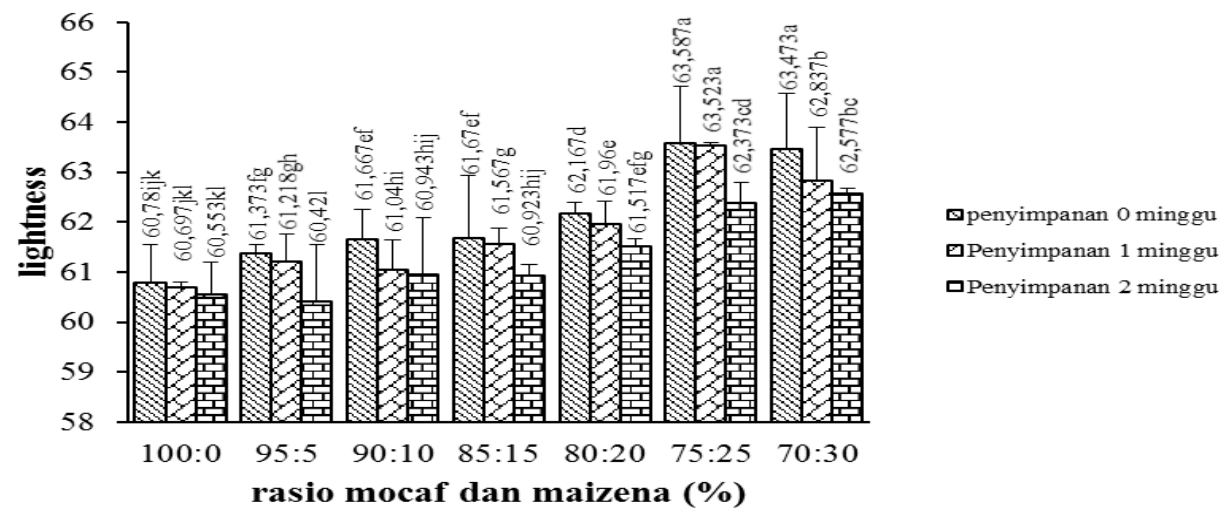

Gambar 4. Grafik nilai lightness cookies green tea

\section{Perlakuan Terbaik}

Formulasi terbaik ditentukan dengan menggunakan uji efektivitas. Penentuan tepung premiks cookies terbaik ditentukan berdasarkan sifat kimia (kadar air, Aw) tepung premiks, sifat fisik cookies (tekstur: hardness, fracture; warna: lightness, chroma). Hasil uji efektivitas tepung premiks cookies dapat dilihat pada Gambar 5. Berdasarkan grafik tersebut, dua formula terbaik yaitu perlakuan 75 MOCAF: 25 maizena memiliki nilai efektifitas 0.74 dan 70 MOCAF: 30 maizena (\%) memiliki nilai efektifitas 0.71 dengan lama penyimpanan yang sama yaitu 2 minggu. 


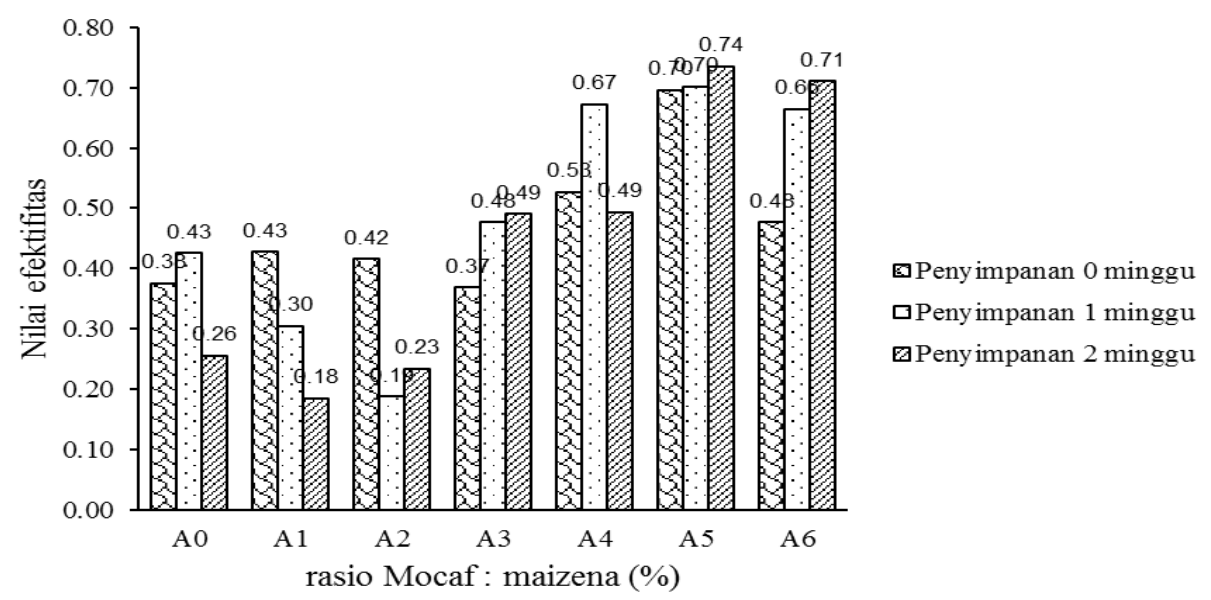

Gambar 5. Grafik Nilai Efektivitas Cookies Green Tea

\section{Sifat Organoleptik}

Salah satu faktor yang menentukan mutu cookies green tea adalah nilai organoleptik adalah. Sifat organoleptik yang diamati pada cookies green tea meliputi warna, rasa, aroma, tekstur, kenampakan, dan penerimaan keseluruhan. Hasil organoleptik cookies green tea terdapat dalam Gambar 6.

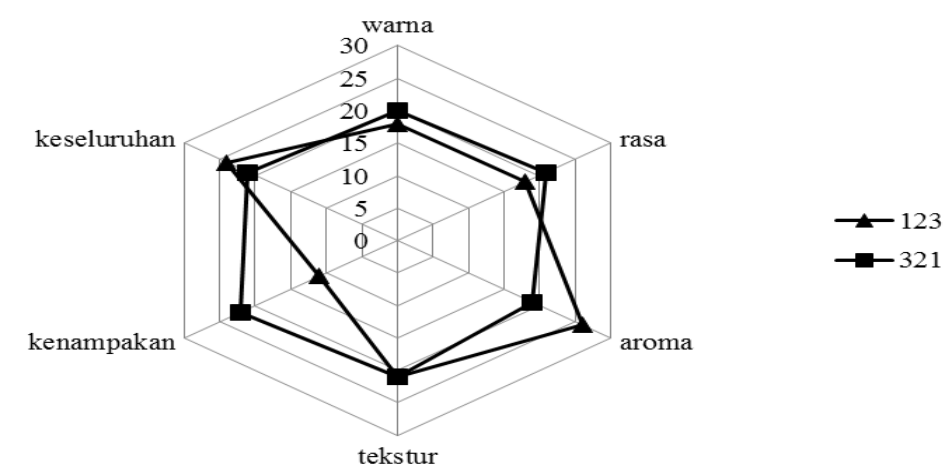

Gambar 6. Grafik Nilai Penerimaan Cookies Green Tea

\section{Warna}

Warna adalah parameter yang memberikan pengaruh kesukaan dan penerimaan panelis untuk produk pangan dan yang paling cepat memberikan kesan, tetapi sulit dalam pengukuran nya sehingga sangat bersifat subyektif. Sebanyak $60 \%$ panelis menerima cookies formula 75\% MOCAF: 25 maizena, 66.67\% panelis menerima warna cookies formula 70\% MOCAF: 30\% Maizena. Cookies dengan formula 70 MOCAF: 30 maizena cenderung menghasilkan warna yang lebih diterima panelis jika dibandingkan dengan formula 75 MOCAF: 25 maizena karena dianggap dari segi warna lebih menarik. Proporsi penambahan maizena yang lebih banyak menghasilkan warna cookies lebih cerah.

Rasa

Panelis lebih cenderung lebih menerima cookies green tea dengan formula 70 MOCAF: 30 maizena sebanyak 70\% dibandingkan dengan formula 75 MOCAF: 25 maizena. Ini dikarenakan adanya penambahan maizena dapat mengurangi rasa dominan dari MOCAF. MOCAF merupakan tepung singkong hasil modifikasi menggunakan bakteri asam laktat sehingga agak berasa asam karena adanya asam laktat yang dihasilkan (Subagio et al., 2008). 
Aroma

Hasil penilaian panelis terhadap aroma cookies green tea yaitu sebanyak $86.67 \%$ panelis lebih menerima cookies dengan formula 75 MOCAF: 25 maizena dibandingkan formula 70 MOCAF: 30 maizena. Adanya penambahan maizena dapat mengurangi aroma dominan dari MOCAF karena bau khas agak asam dari MOCAF dihasilkan dari aktivitas bakteri asam laktat dalam proses fermentasi pembuatannya. Subagio et al. (2008), proses fermentasi selama pembuatan MOCAF melibatkan mikroba yang mampu memproduksi enzim-enzim yang dapat menghidrolisis pati menjadi gula sederhana dan kemudian menjadi asam-asam organik khususnya asam laktat yang menimbulkan bau khas pada MOCAF.

Tekstur

Hasil penilaian panelis menunjukkan bahwa sebanyak $70 \%$ panelis menerima cookies dengan formula 75 MOCAF: 25 maizena sama banyak dengan penilaian tekstur cookies formula 70 MOCAF: 30 maizena. Struktur cookies yang kokoh dihasilkan dari amilopektin yang memiliki kemampuan perekat (Harzau dan Estiasih, 2013). Selain itu, kandungan air pada maizena cukup rendah (15\%) (BSN, 1994) sehingga menghasilkan produk yang renyah.

\section{Kenampakan}

Hasil penilaian panelis menunjukkan bahwa sebanyak $73.33 \%$ panelis menerima kenampakan cookies dengan formula 70 MOCAF: 30 maizena. Penambahan maizena pada pembuatan cookies menghasilkan kenampakan yang lebih baik pada atribut mutu cookies. Pati jagung memiliki amilopektin yang lebih tinggi daripada amilosa. Perbandingan amilosa dan amilopektin berpengaruh dalam pembentukan tekstur cookies sehingga kenampakan cookies juga menjadi lebih meningkat.

\section{Keseluruhan}

Hasil penelitian panelis menunjukkan bahwa sebanyak $80 \%$ panelis menerima cookies dengan formula 75 MOCAF: 25 maizena. Oleh karena itu secara keseluruhan panelis lebih menerima cookies dengan formula 75 MOCAF: 25 maizena. Tingkat penerimaan keseluruhan ditentukan berdasarkan akumulasi semua karakteristik organoleptik yang diujikan kepada panelis meliputi warna, rasa, aroma dan tekstur dari cookies green tea.

Uji validitas

Berdasarkan uji efektivitas disimpulkan bahwa, penerimaan cookies dari data angket yang ada adalah valid, sehingga dapat digunakan sebagai penelitian. Hasil perhitungan uji validitas menunjukkan bahwa semua nilai $r_{\text {hitung }}>r_{\text {tabel }}$ pada nilai signifikasi $5 \%$ (Tabel 2 ).

Table 2. Hasil Validitas Angket Penerimaan Cookies Green Tea

\begin{tabular}{ccccc}
\hline Karakteristik & $\mathrm{r}_{123}$ & $\mathrm{r}_{321}$ & $\mathrm{r}_{\text {tabel }} 5 \%(30)$ & Keterangan \\
\hline Warna & 0.883 & 0.611 & 0.361 & Valid \\
Rasa & 0.579 & 0.386 & 0.361 & Valid \\
Aroma & 0.644 & 0.379 & 0.361 & Valid \\
Tekstur & 0.545 & 0.669 & 0.361 & Valid \\
Kenampakan & 0.647 & 0.394 & 0.361 & Valid \\
Keseluruhan & 0.727 & 0.905 & 0.361 & Valid \\
\hline
\end{tabular}

Uji Reliabilitas

Berdasarkan uji reliabilitas dapat disampaikan bahwa data dalam angket penerimaan cookies adalah reliable, sehingga dapat digunakan sebagai instrument penelitian. Instrument dapat dikatakan reliabel jika nilai alpha lebih besar dari $r_{\text {tabel }}(0.361)$. 
Tabel 3. Hasil Reliabilitas Angket Penerimaan Cookies Green Tea

\begin{tabular}{cccc}
\hline Variabel & $r_{\text {hitung }}$ & $r_{\text {tabel }} 5 \%(30)$ & Keterangan \\
\hline 123 & 0.75 & 0.361 & Reliabel \\
321 & 0.555 & 0.361 & Reliabel \\
\hline
\end{tabular}

Kadar air

Hasil analisis nilai kadar air tepung premiks cookies (Tabel 4) menunjukkan bahwa pada formula 75 MOCAF: 25 maizena memiliki kadar air lebih tinggi jika dibandingkan dengan formula 70 MOCAF: 30 maizena tetapi, berdasarkan hasil Annova pada taraf uji 5\% dihasilkan nilai kadar air tidak berbeda nyata dari kedua jenis tepung premiks tersebut. Kadar air kedua tepung premiks yang dihasilkan masih berada dibawah SNI (maksimal $12 \%)$.

Tabel 4. Sifat Kimia Tepung Premiks Cookies

\begin{tabular}{cccccc}
\hline Sampel & \multicolumn{5}{c}{ Analisis } \\
\cline { 2 - 6 } & $\begin{array}{c}\text { Kadar Air } \\
(\%)\end{array}$ & $\begin{array}{c}\text { Protein } \\
(\%)\end{array}$ & $\begin{array}{c}\text { Lemak } \\
(\%)\end{array}$ & $\begin{array}{c}\text { Abu } \\
(\%)\end{array}$ & $\begin{array}{c}\text { Karbohidrat } \\
(\%)\end{array}$ \\
\hline $75 \%$ MOCAF: 25\% maizena & $8.55 \mathrm{a}$ & $2.11 \mathrm{~b}$ & $1.80 \mathrm{~b}$ & $0.76 \mathrm{~b}$ & $86.75 \mathrm{a}$ \\
$70 \%$ MOCAF: 30\% maizena & $8.53 \mathrm{a}$ & $2.18 \mathrm{a}$ & $1.84 \mathrm{a}$ & $0.78 \mathrm{a}$ & $86.70 \mathrm{a}$ \\
\hline
\end{tabular}

Kadar Protein

Hasil analisis protein tepung premiks cookies formula 75 MOCAF: 25 maizena sedikit lebih rendah dibandingkan formula 70 MOCAF: 30 maizena. Berdasarkan hasil ANOVA pada taraf uji $5 \%$ dihasilkan nilai kadar protein yang berbeda nyata antar kedua formula tepung premiks tersebut. Nilai kadar protein tepung premiks dapat dilihat pada Tabel 4. Kandungan protein cookies berbahan dasar tepung dengan penambahan tepung terung lebih tinggi (8.12-8.40\%) (Uthumporn et al., 2014), tepung beras (9.88-7.95\%) (Mounika et al., 2017), dan sorgum-talas-kekacangan (4.85-19.89\%) (Okpala et al., 2012) dibandingkan cookies grean tea MOCAF. Ini disebabkan karena kadar protein MOCAF lebih rendah (max. $1.2 \%)$ daripada tepung terigu (8.9\%) (Wulandari dan Handarsari, 2010).

\section{Kadar lemak}

Hasil analisis lemak tepung premiks cookies yaitu 1.8\% (75 MOCAF: 25\% maizena) dan $1.84 \%$ (70\% MOCAF: 30 maizena). Berdasarkan hasil ANOVA pada taraf uji 5\% dihasilkan nilai kadar lemak yang berbeda nyata dengan perbedaan rasio MOCAF dan maizena. Nilai kadar lemak tepung premiks cookies green tea lebih rendah dari premiks sorgum-talas-kekacangan (5.64-6.84\%) (Okpala et al., 2012), dan beras coklat-terigu (27.19-27.28\%) (Mounika et al., 2017).

Kadar abu

Hasil analisis abu tepung premiks cookies yaitu $0.76 \%$ (75\% MOCAF: $25 \%$ maizena) dan 0.78\% (70\% MOCAF: 30\% maizena). Berdasarkan hasil ANOVA pada taraf uji 5\% dihasilkan nilai abu yang berbeda nyata pada formula yang berbeda. Nilai kadar abu tepung premiks MOCAF lebih rendah daripada cookies dari beras coklat-terigu (0.96-1.12\%) (Mounika et al., 2017), terigu-terung (1.57-1.97\%) (Uthumporn et al., 2014), dan sorgumtalas-kekacangan (2.37-2.73\%) (Okpala et al., 2012).

Kadar Karbohidrat

Hasil analisis karbohidrat tepung premiks cookies yaitu $86.75 \%$ dan $86.7 \%$. Berdasarkan hasil ANOVA pada taraf uji $5 \%$ dihasilkan nilai karbohidrat yang tidak berbeda nyata antara formula 75\% MOCAF: $25 \%$ maizena dan $70 \%$ MOCAF: $30 \%$ maizena. Nilai kadar karbohidrat tepung premiks lebih besar dibandingkan cookies dari beras coklat-terigu (60.66-60.98\%) (Mounika et al., 2017), terigu-terung (61.10-63.94\%) (Uthumporn et al., 2014), dan sorgum-talas-kekacangan (57.77-72.28\%) (Okpala et al., 2012). 


\section{SIMPULAN}

Proporsi bahan baku dan lama penyimpanan tepung premiks cookies green tea berpengaruh terhadap kadar air dan aktivitas air. Formula cookies green tea MOCAF terbaik berdasarkan uji efektivitas adalah rasio penambahan 75\% MOCAF: $25 \%$ maizena dengan lama penyimpanan 2 minggu. Karakteristik tepung premiks formula terbaik yaitu kadar air $8.55 \%$, kadar abu $0.76 \%$, kadar protein $2.11 \%$, kadar lemak $1.80 \%$, kadar karbohidrat $86.75 \%$ sedangkan untuk produk cookies green tea dari formula terbaik tersebut memiliki karakteristik kekerasan $0.07(\mathrm{~g} / \mathrm{mm})$, daya patah $151.62(\mathrm{~g} / \mathrm{mm})$, chroma 27.25, kecerahan 62.37. Pencetakan cookies perlu menggunakan alat cetak yang sesuai sehingga didapatkan ukuran yang seragam.

\section{DAFTAR PUSTAKA}

Ahmed, M.A.H. 2015. Effect of storage temperature and periods on some characteristics of wheat flour quality. Food and Nutrition Sciences 6: 1148-1159.

Anwar, M.A., Windrati, W.S., N, Diniyah. 2016 Karakterisasi Tepung Bumbu Berbasis MOCAF (Modified Cassava Flour) dengan Penambahan Maizena dan Tepung Beras. Jurnal Agroteknologi 10:2, 167-179

AOAC. 2000. Official Methods of Analysis of The Association of Official Analytical Chemists. Washington DC.

Apriyani, R.R.N., Arpah, M., Setyadjit. 2011. Formulasi Tepung Komposit Campuran Tepung Talas, Kacang Hijau dan Pisang dalam Pembuatan Brownies Panggang. Jurnal llimiah dan Penelitian IImu Pangan 12:2.

Badan Standarisasi Nasionan (BSN). 1994. Maizena SNI 01-3351. Jakarta.

Badan Standarisasi Nasional. 2011. Standar Nasional Indonesia Syarat Mutu Kue Kering (Cookies) SNI 01-2973-2011. Jakarta.

Badan Standarisasi Nasionan (BSN). 2011. Tepung Mocaf SNI 7622:2011. Jakarta.

Banerjee, C., Singh, R., Jha, A., and Mitra, J. 2014. Effect of Inuline on Textural and Sensory Characteristics of Sorghum Based High Fibre Biscuits Using Response Surface Methodology. Journal of Food Science Technology 51:2762-2768.

Company Report. 2016.2 Fast Food Indonesia. https://www.miraeasset.co.id/files/bbs/01202/7741_1.pdf

De Garmo, E.P., Canade, J.R. dan Sullivan , W.G. 1984. Engineering Economy. MacMillan Publishing. New York: Seventh Edition.

Diniyah, N., Windrati, W.S., Nafi', A., P.H., Istiani. 2013. Perubahan Sifat Fisik dan Kimiawi Kue Bika Ambon Termodifikasi dengan Penambahan Tepung Mocaf (Modified Cassava Flour). Prosiding Seminar Nasional PATPI. Jember 26-29 Agustus.

Diniyah, N., Puspitasari, A., Nafi, A., A, Subagio. 2016. Characteristic of Analog Rice Using Hot Extruder Twin Screw. Jurnal Penelitian Pascapanen Pertanian 13:1, 36-42.

Diniyah, Firdaus, L., Windrati, W.S., A., Nafi, A., Prasetyo, A., A, Subagio. 2016. Indeks Glikemik Beras Analog dari Mocaf dengan Substitusi Jagung, Ubi Jalar Ungu dan Wortel. Warta Industri Hasil Pertanian 33:2, 66-73.

Diniyah, N., Setiawati, D., Windrati, W.S., A, Subagio. 2017. Karakterisasi Mi Mojang (Mocaf-Jagung) dengan Perbedaan Jenis dan Konsentrasi Bahan Pengikat. Jurnal Penelitian Pascapanen Pertanian 14:2, 98-107.

Diniyah, N., Agustin, F.D., Setiawan, D., Subagio, A., Windrati, W.S. 2017. Teknik Ekstrusi Dingin pada Mie MOJANG (Mocaf-Jagung) dengan Variasi Proporsi Bahan Baku dan Lama Pengukusan Adonan. Jurnal Penelitian Pangan 2:1, 69-75.

Estiasih, T., dan Ahmadi, K. 2009. Teknologi Pengolahan Pangan. Bumi Aksara. Jakarta.

Fennema, O.R. 1996. Food Chemistry. Marcel Dekker. New York. 
Harzau, H dan Estiasih. T. 2013. Karakteristik cookies umbi inferior uwi putih (kajian proporsi tepung uwi: pati jagung dan penambahan margarin). Jurnal Pangan dan Agroindustri 1:138-147.

Hutching, J.B. 1999. Food Colour and Appearance. Aspen Publishers. Marylan.

Kumar, K.A., Sharma, G.K., Khan, M.A., Govindaraj, T., and Semwal, A.D. 2015. Development of Multigrain Premixes-Its Effect on Rheological, Textural and MicroStructural Characteristics of Dough and Quality of Biscuits. Journal Food Science and Technology 52:12, 7759-7770.

Kumar, K.A., Sharma, G.K., Khan, M.A., Semwal, A.D. 2015. Optimization of Multigrain Premix for High Protein and Dietary Fibre Biscuits Using Response Surface Methodology (RSM). Food and Nutrition Science 6: 747-756.

Mounika, B., Suchiritha, D.S, Uma, M.K, Hemalatha, V., Supraja, T. 2017. Physical, Proximate and Nutritional Composition of Cookies Incorporated with Germinated Brown Rice. The Pharma Inovation 6:7, 958-961.

Nadhifah, M., Diniyah, N., Windrati, W.S., A, Subagio. 2016. Sifat Fisik, Kimia, Organoleptik Rempeyek Berbahan MOCAF (Modified Cassava Flour). Prosiding Seminar Nasional APTA. Jember 26-27 Oktober. 186-191.

Okaka, J.C., and M.I. Isieh. 1990. Development and quality evaluation of cowpea wheat biscuits. Niger. Food Journal 8: 56-62.

Okpala, L., Okoli, E., Udensi, E. 2012. Physico-Chemical and Sensory Properties of Cookies Made from Blends of Germinated Pigeon Pea, Fermented Sorghum, and Cocoyam Flours. Food Science and Nutrition 1:1, 8-14.

Perez-Carrilli, E., Frias-Escobar, A., Gutierrez-Mendivil, K., Guajardo-Flores, S., SernaSaldivar, S.O. 2017. Effect of maize starch substitution on physicochemical and sensory attributes of gluten-free cookies produced from nixtamalized flour. Journal of Food Processing 1-7.

Prameswari, R.D dan Estiasih, T. 2013. Pemanfaatan tepung gembili (Dioscorea esculenta) dalam pembuatan cookies. Jurnal Pangan dan Agroindustri 1:1, 115-128.

Rachman, I.D. 2012. Studi Pembuatan Tapioca Fermented Flour (TFF) dengan Fermentasi Alami dan Penambahan Inokulum. Jurusan Teknologi Pertanian. Fakultas Pertanian. Universitas Hasanuddin: Makasar.

Rambitan, J. 1988. Isolasi dan Karakterisasi Pati dari beberapa Varietas Jagung. Tesis. Institut Pertanian Bogor: Bogor.

Rosmisari, A. 2006. Review: Tepung Jagung Komposit, Pembuatan dan Pengolahannya. Prosiding Seminar Teknologi Inovatif Pascapanen Pengembangan Pertanian. Balai Besar Penelitian dan Pengembangan Pascapanen Pertanian, Bogor.

Saeleaw, M. and Schleining, G. 2010. Effect of blending cassava starch, rice, waxy rice and wheat flour on physico-chemical properties of flour mixtures and mechanical and sound emission properties of cassava crackers. Journal of Food Engineering 100: $12-24$.

Santoso, D.D.S. 2009. Pemnafaatan tepung premix berbahan dasar mutan sorgum zh-30 untuk industry pembuatan adonan dan mie kering. Jurnal IImiah Aplikasi Isotop dan Radiasi 5: 1-21

Seyhun, N., Sumnu, G., Sahin, S. 2003. Effects of Different Emulsifier Types, Fat Contents, and Gum Types on Retardation of Stalling of Microwave-Baked Cakes. Nahrung 47:4, 248-251.

Skrbic, B., and Cvejanov, J. 2011. The Enrichment of Wheat Cookies with High-Oleic Suflower Seed and Hull-Less Barley Flour: Impact on Nutritional Composition, Content of Heavy Elements and Physical Properties. Food Chemistry 124: 1416-1422

Subagio, A., Windrati, W.S., Witono, Y., dan Fahmi, F. 2008. Prosedur Operasi Standar (POS): Produksi Mocal Berbasis Klaster. Kementerian Negara Riset dan Teknologi. Jakarta

Taewee, T.K. 2011. Cracker 'keropok': a review on factors influencing expantion. International Food Research Journal 18: 855-866. 
Tongdang, T., Meenun, M., and Chainui, J. 2008. Effect of sago starch addition and steaming time on making cassava cracker (Keropok). Starch/Starke 60: 568-576.

Tovar, J.C., Melitoa, E., Herrerra, A., Rascon, E., Perez. 2002. Resistant Starch Formation Dosen not Parallel Syneresis Tendency in Different Starch Gels. Food Chemistry 76: 455-459

Uthumporn, U., Woo, W.L., Tajul, A.Y., Fazilah, A. 2015. Physico-Chemical and Nutritional Evaluation of Cookies with Different Levels of Eggplant Flour Substitution. Cyta Journal of Food 13:2, 220-226

Utomo, L.I.V.A., Nurali, E., Ludong, M. 2017. Pengaruh Penambahan Maizena pada Pembuatan Biscuit Gluten Free Casein Free Berbahan Baku Tepung Pisang Goroho (Musa acuminate). Cocos 1:2, 1-12

Wulandari, M., dan Handarsari, E. 2010. Pengaruh Penambahan Bekatul terhadap Kadar Protein dan Sifat Organoleptik Biskuit. Jurnal Pangan dan Gizi, 1:2, 55-62. 